\title{
A Study on the Construction of School-enterprise Customized Curriculum for Employment-oriented Japanese
}

\author{
Wanlong Zhu \\ Dalian Neusoft Institute of Information \\ Dalian, China 116023
}

\begin{abstract}
The market should understand the current needs of Japanese professionals. According to the analysis on the current situation of employment and professional development, it can improve the current Japanese education model. And it also can find out the development of Japanese industry. Then, it would explore the construction of school-enterprise customized curriculum for Japanese. It could achieve personnel training objectives with the social needs. And it can improve the students' employment and practical workability. It could make up for the shortage of the construction of schoolenterprise courses in colleges and universities. In the end, it would provide Japanese talent for the development of local economy.
\end{abstract}

Keywords-the co-construction course of school and enterprise; employment status; applied Japanese talent

\section{INTRODUCTION}

With the rapid development of China's economy, the demand for Japanese professionals in modern society is not limited to the professional level of students. In the recruitment of talent, enterprises pay more attention to professional ability, the innovation ability, interpersonal skills and the ability to solve practical problems. At present, the major colleges and universities have promoted innovative education to be the mainstream of higher education in the 21 st century. Particularly, it is concerned about the innovative school-enterprise cooperation model. It is an important way to cultivate talents to meet the needs of the society. And it is also the fundamental goal of China's higher education reform and development. According to the continuous development of the BPO with Japan, BPO with Japan has been upgraded from the low-level BPO, which is mainly typed in Japanese, to the high-level BPO with purchasing, finance and human resources. Therefore, it needs the Japanese talents with good Japanese ability and certain financial foundation or the compound talents with IT knowledge in the current market. To establish the cooperative relationship between universities and enterprises has become an urgent problem to be solved for colleges and universities in our country. The school and enterprise could build a customized model. Then, it may effectively solve the seamless docking between personnel training and the needs of business. The paper will carry out practical research on the formulation of the personnel training program on schoolenterprise construction of customized curriculum, the construction of the curriculum system and the direction of future development.

\section{THE CONSTRUCTION MODEL OF SCHOOL-ENTERPRISE CUSTOMIZED CURRICULUM OF JAPANESE}

\section{A. The Current School-enterprise Cooperation Model of Japanese}

Through the current Japanese professional practice course, it can send interns to the enterprise. And it is the main mean. The students would have practice and application ability in the enterprise practice. It considers the current capacity of college students to measure the needs of enterprises through recruiting the interns in schools. Through the cooperation with enterprises, the school would complete the training objectives, and collect the feedback information to set up personnel training programs and curriculum system. After the internship, the enterprise will screen out some outstanding staff to become employees in accordance with the actual work situation. The school will also allow students to return to school. These students can make reports and other things to provide work experience for undergraduate.

The school-enterprise cooperation model provides a certain practice platform for the students. However, the coverage is limited. Generally, only a small part of the students can get such an opportunity in the professional. In the actual work, some students don't want to participate in business practice. They believe that they can promote themselves in the school according to learn more professional knowledge. It has been associated with the practice of recruiting internship and the construction of school curriculum system over the years. In the recruitment of Japanese professional interns, the people who do information entry often work in the bottom of the enterprise. Work is relatively boring, and students are difficult to do for a long time. In the feedback information, it is said that the skills of students aren't highly matched with the practical work. And it also scares the students off it. Therefore, to build a school-enterprise course of Japanese is the most important task today. 
B. The Construction Mode and Practice of Innovative School-enterprise Course of Japanese

1) The construction model of innovative schoolenterprise construction of customized curriculum of Japanese: The employment-oriented school-enterprise curriculum aims to introduce the enterprise into the construction of personnel training program of the universities and colleges and the curriculum system. While it emphasizes the construction of the practice base outside the school, it must also dare to innovate and actively study the use of social resources to explore the market demand. With the introduction of resources outside the school, it must establish a system in line with the needs of the curriculum system to train the necessary personnel to do business. At present, the construction mode of innovative school-enterprise customized course for employmentoriented Japanese has two types.

- Colleges and universities take the initiative to customize the model. According to the needs of the enterprise, colleges and universities take the initiative to customize the relevant courses for enterprises to transport the required applied Japanese talent. In 2012 - 2016, it has been around the enterprise needs in the initiative customized mode of the universities and colleges for five years. And it established Japanese customized classes. It has cultivated a total of more than 200 students. The rate is up to $98 \%$. All of these students have entered into the counterparts to work. In 2016, the customized course was included in the training program of the Japanese department. And the customized course was added to the practical teaching of junior students.

- Enterprises take initiative to customize model. The enterprises take the initiative to participate in the construction of customized courses or curriculum system. And they would send trainers to involve in customized courses. Since 2017, the Japanese department has established a school-enterprise customized training system. It has considered the needs of the enterprises. Then, it has established business Japanese document processing (the first), business Japanese document processing (the second), computer Japanese, Japanese note, information Japanese certification, Genpact customized course. It has completed the training of qualified personnel from the shallower to the deeper. Genpact schoolenterprise customized courses are taught by the enterprise trainers. The specific course of the semester and training capacity can be seen in "Table I".

TABLE I. GENPACT SCHOOL-ENTERPRISE CUSTOMIZED CURRICULUM SYSTEM

\begin{tabular}{|l|l|l|l|}
\hline \multicolumn{1}{|c|}{ Title of Course } & \multicolumn{1}{|c|}{$\begin{array}{c}\text { To Open } \\
\text { Semester }\end{array}$} & Corresponding Position & \multicolumn{1}{c|}{$\begin{array}{c}\text { Corresponding } \\
\text { Ability }\end{array}$} \\
\hline $\begin{array}{l}\text { The Processing Practice of } \\
\text { Business Japanese Document (1) }\end{array}$ & $\begin{array}{l}\text { The Third } \\
\text { Semester }\end{array}$ & $\begin{array}{l}\text { BPO Background Service } \\
\text { with Japan }\end{array}$ & Word、PPT \\
\hline $\begin{array}{l}\text { The Processing Practice of } \\
\text { Business Japanese Document (2) }\end{array}$ & $\begin{array}{l}\text { The Sixth } \\
\text { Semester }\end{array}$ & $\begin{array}{l}\text { BPO Background Service } \\
\text { with Japan }\end{array}$ & Excel \\
\hline Computer Japanese & $\begin{array}{l}\text { The Seventh } \\
\text { Semester }\end{array}$ & $\begin{array}{l}\text { BPO Background Service } \\
\text { with Japan }\end{array}$ & IT Passport/TAC \\
\hline The Note of Japanese Business & $\begin{array}{l}\text { The Eighth } \\
\text { Semester }\end{array}$ & Financial BPO with Japan & Finance/ TAC \\
\hline Information Japanese Certification & $\begin{array}{l}\text { The Eighth } \\
\text { Semester }\end{array}$ & $\begin{array}{l}\text { BPO Background Service } \\
\text { with Japan }\end{array}$ & IT Passport/TAC \\
\hline Genpact Customized Course & $\begin{array}{l}\text { The Ninth } \\
\text { Semester }\end{array}$ & BPO Processing services & PSCS with Japan \\
\hline
\end{tabular}

2) The practice of school-enterprise customized courses of Japanese: The deputy director of Japanese department of Dalian Neusoft Institute of Information and human resources manager of Genpact (Dalian) Co., Ltd. should take charge of the school-enterprise customized courses. Under the unified leadership of both parties, the participators include senior director of Japanese professional management team, deputy director, manager of training department and the relevant leaders of business department. The ultimate goal is to send the students who participate in the Genpact customized course to the Genpact Company. The specific cooperation process can be seen in "Fig. 1".

After the completion of the customized course, 22 students participating in this customized course signed an internship agreement with Genpact. They entered the company to be a trainee. And finally, it reached employment after the internship. In this cooperation between Japanese department and Genpact (Dalian) Co., Ltd., the two parties have made positive exchange and cooperation on student internships, practice, curriculum integration, cultivation and other aspects. After the customized course, we returned to Genpact (Dalian) Co., Ltd. and invited the training manager of the company to participate in the development of the construction of the future course of the Japanese department. They have made deep discussion on the curriculum development, teaching materials selection, teacher training and other aspects of the future development of customized courses. And the training managers of Genpact have been the honorary teachers of Neusoft Japanese department. 


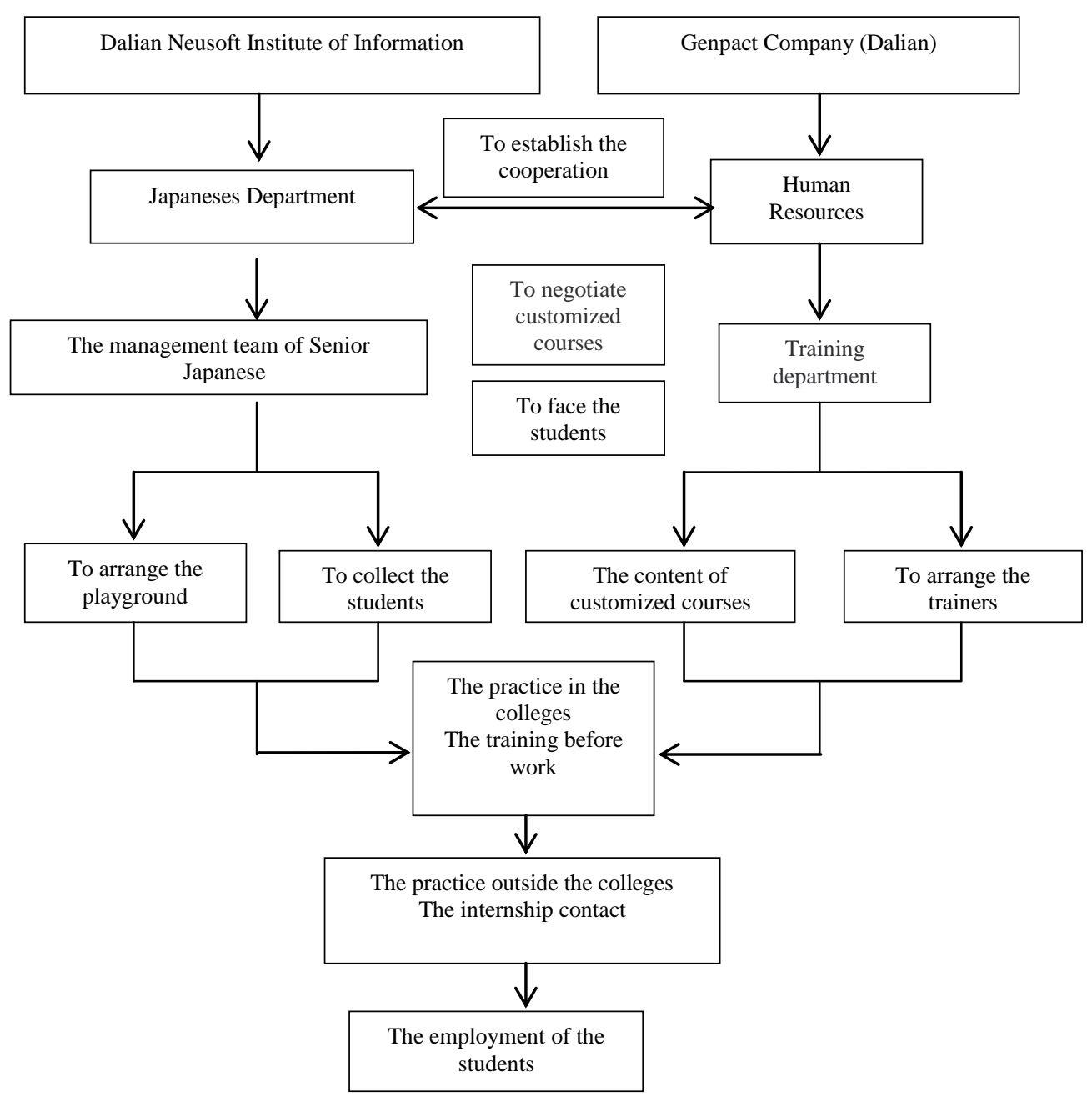

Fig. 1. The cooperation process of Genpact school-enterprise customized curriculum.

The school-enterprise customized courses mainly include nine modules: SOP foundation; business etiquette; PC Skill (Excel, PPT); communication skills; procurement; Japanese honorifics; professional development; mail writing; production management; It has counted a total of 80 hours. In the process of learning, students gradually understand the culture of Genpact and the workplace literacy. At the same time, they master the skills required for PSCS business with Japan, and clear their career development direction in the future. Students are actively involved in classroom interaction. They have improved their ability to show themselves, build confidence under the guidance of corporate trainers and understand the importance of innovative thinking in the enterprise. According to the feedback of students after class, it is generally believed that their application ability of Japanese professional knowledge and practical business ability has been greatly improved through this course. For the enterprise, the training of the trainees can be completed in the school. It saves the training costs. And the students also acquire the basic skills required for enterprises in the school-enterprise customized curriculum system in advance. And then, it would also shorten the training time. For students, through the schoolenterprise customized courses, they could not only open up their horizons, enhance their professionalism, but also improve the practical ability and adaptability, strengthen the sense of service, and further clarify the future career goals. For colleges and universities, through the school-enterprise customized courses, it could clear the development direction of the construction of professional curriculum and personnel training in the future. It also could provide more choices for students. Students have a good working environment. When they return to school, they would share the work experience. Also, they can bring good reputation and positive information for the schools. Therefore, the establishment of school-enterprise courses is conducive to colleges and universities, students and enterprises. It would achieve mutual benefit for schools and enterprises.

Through the practice of the above-mentioned schoolenterprise customized curriculum system, it is proved that the implementation and the final result of the enterprises' active customization model are more significant than the single-oriented customization model. 


\section{THE DEVELOPMENT OF SCHOOL-ENTERPRISE} CUSTOMIZED CURRICULUM OF JAPANESE IN THE FUTURE

The implementation and development of schoolenterprise customized curriculum of Japanese not only can affect the employment prospects of students, but also can enhance the business needs of college graduates. According to their conditions and the local economic development, business needs, market changes and other factors, colleges and universities should develop the school-enterprise customized courses with their characteristics. Combined with their own conditions, it should establish the school-enterprise customized model with their own characteristics.

In the school-enterprise cooperation, In the future, it would cooperate with Yida, Wistron, Nomura and other world's top 500 enterprises to build customized schoolenterprise curriculum. In 2018, the number of participating in school-enterprise customized curriculum will reach to 3-4. It is expected that 80-100 students will be allowed to enter the cooperative business to have practice. And eventually, they would complete the employment. It could solve the employment of nearly half of graduates of Japanese department to achieve a real win-win situation between school and enterprise.

In terms of the construction of teaching staff, the colleges and universities should encourage professional teachers to accept the training of enterprises, and to go into the enterprise to have practice. In the end, it can improve the proportion of "cross-professional guidance" teachers. At the same time, it should invite the professional training personnel to enter the university to undertake or participate in the implementation and construction of relevant courses. Then, they can implement the work policy of "go out, and bring in" to construct the teaching staff. It also should improve the honorary lecturer to rich teacher resources.

\section{CONCLUSION}

The developing colleges and universities should learn from the advanced experience of practical teaching model of all kinds of colleges and universities. And they also should develop and construct school-enterprise customized courses with their professional characteristics. It is an essential way to survive and develop the Japanese of the colleges and universities to promote innovative school-enterprise construction of Japanese course. It is also the necessary way to cultivate the applied Japanese talents. The schoolenterprise construction of Japanese should run through the concept of "employment-oriented" development, and implement the educational philosophy of "to learn in practice, and to practice in learning". The curriculum has the conditions of "integration, diversification". And it should strive to achieve school-enterprise docking, broaden the field, strengthen the practice, and promote employment. Then, it can provide high-quality application of Japanese talents for the local economic construction.

\section{REFERENCES}

[1] Li Yinan, Zhao Zhixiang. The new model cooperation between industry and academia - The innovative service model based on active customization[J]. Huazhang Press, 2014 (16):

[2] Lv Ruquan. A Study on the Application of Practice in the Combination of Officials and obstetics - Taking Japanese in Private Colleges as an Example [J]. Jilin, Journal of Agricultural Science and Technology, 2013 (2): 66-68

[3] Gao Jiaqi, Ma Jian. Research on the cultivation of applied talents in local colleges and universities based on industry - university cooperation [J]. Caizhi Press, 2015 (8): 226 